\title{
Indonesia's Response to Covid-19 Outbreak: Raising Awareness through Community Engagement and Actionable Volunteer Contribution
}

\author{
http://dx.doi.org/10.25008/jkiski.v6i2.596
}

\author{
Janette Maria Pinariya $^{1^{*}}$, Carelyn Josphine ${ }^{2}$, Wulan Yulianti ${ }^{3}$, \\ Anita Yunia ${ }^{4}$ \\ ${ }^{1234}$ Communication Study in Postgraduate Programme, Institut Komunikasi dan Bisnis LSPR \\ Sudirman Park, Jl. KH. Mas Mansyur Kav. No. 35 Jakarta 10220 - Indonesia \\ *Corresponding author: janette.mp@1spr.edu
}

Submitted: August 10, 2021, Revised: September 09, 2021, Accepted: November 30, 2021

Accredited by Kemristekdikti No. 28/E/KPT/2019

\begin{abstract}
The world is in the grip of a health crisis due to the unforeseen consequences of the COVID-19 pandemic causing a substantial increase in distress associated with pain, depression, and loss. Indonesia is not handling the epidemic properly at this early stage due to a lack of planning and readiness on the part of the country. The government subsequently established the COVID-19 national task force, a COVID-19 assistance centre that reflects the government's readiness and urgency in dealing with the COVID-19 pandemic. At the national and regional levels, the task force reports directly to the president, organizes and encourages all connected agencies to respond to the COVID-19 crisis. The task force's other responsibility is to raise awareness about COVID-19 to the general public. The study aims to determine how Indonesia's COVID-19 task force volunteers can act as a communication aid for the public as a source of empowerment during the pandemic, as well as to examine risk communication and community engagement. This research uses a qualitative approach using the theory of social support. As a result, this study has identified new volunteering approaches for Indonesia's COVID-19 task force that could act as a support system as well as improvements on their approach on community engagement with the public.
\end{abstract}

Keywords: Covid-19; volunteering; social support; community engagement; communication

\section{Introduction}

The world is in the grip of a health crisis, whether emotional or physical. The concern has resulted in a global catastrophe, with the unforeseen consequences of the COVID-19 pandemic causing a substantial increase in distress associated with pain, depression, and loss. A new strain of SARS-CoV-2, also known as the coronavirus, was discovered in December 2019 in Wuhan, a city in China's Hubei province, following an outbreak of pneumonia with no apparent cause crisis. (Financial Times 2020) reported that the country was already 10 days into Chunyun, the Lunar New Year travel season that is also the largest annual human migration on the planet. The government has finally verified the virus's yet-unnamed humanto-human dissemination.

The virus spreads at various rates in different countries, based on a variety of factors such as cultural and behavioural responses of the group, population density, average household size, and so on. The figures above show the outbreak was initially defined by a series of shifting epicentres including larger continents like Europe and Africa, however the 
pandemic has now spread to almost every country in the globe. As of this current writing time, the total reported caseload of COVID-19 has reached more than 126 million, including over 1 million deaths globally. This is a historical stress test for the government, medics, and the public to globally cooperate in order to minimize the chaos. This trend has resulted in considerable differences in countries' preparedness and reactions to the crisis.

Organizations in every industry, all over the world, have been forced to cancel, reduce, or restructure activities and programs for weeks or months, with far-reaching economic and social consequences. Companies and small businesses, schools, charities, and families may still face uncertainty and confusion until all civilians have gotten the safe, readily accessible, and inexpensive vaccines that are produced and delivered globally. The COVID19 situation already threatens the survival of many people. The imposition of social isolation, social distancing, and lockdown policies, shuts down face-to-face worship (Singarimbun, 2021).

Mendy et., al, (2020) stated that Scenario planning becomes important to help anticipate where employees and communities may be in dealing with the crisis, and the appropriate messaging that can help them as the crisis unfolds. Indonesia has also gotten the impact from this disease. Setiati and Azwar (2020) stated that the nation's case fatality rate (CFR) is also much higher than that of the People's Republic of China ( $8.9 \%$ vs $4 \%$ ).

With the bare preparation and readiness from the country, Indonesia is not handling the pandemic well on the early stage. From the first official declaration from the World Health Organization (n.d) the virus has not yet entered Indonesia, which made the government in denial of the harm that could be caused by Coronavirus. The country's first two confirmed cases were reported during early February when a 64-year-old and her 31-year-old daughter had been in contact with a Japanese citizen who tested positive in Malaysia on February 27 after visiting Indonesia. Gorbiano (2020) Civilians and authorities still refused to acknowledge the dangers that could happen. Since the first incident, the virus continues to spread within the country, harming both citizens in and out of Indonesia.

The government's initial handling during the early pandemic did not turn out to be what had been expected. Quoted from Fachriansyah (2020), one of Indonesia's ministers Mahfud
MD even compared the country's response to this virus similar to being married to a woman. As a result of the joke, This has made civilians and other parties involved underestimate the pandemic by not preparing any health protocols to prevent further damage.

As of July 2021, Indonesia's caseload continues to skyrocket as it has reached up to mor than fifty thousand cases daily. This has been a record for Indonesia after two years of battling the pandemic.

As a result, the government has yet to call out another emergency Community Activities Restrictions Enforcement or commonly known as PPKM on the first of July, 2021 by President Jokowi himself. The initial restriction was stated that it will start from 3 - 20 July 2021 especially in the cities of Java and Bali, then extended until the 31 st of July. The task force's official website KPCPEN (2021) reported that the COVID-19 Handling Task Force has 14 thousand volunteers who are currently joining the volunteer field. They have taken initiative since the outbreak began until the Emergency Community Activity Restriction was implemented (PPKM). As for now, data and statistics are still changing until further announcements are declared.

People who live in the digital era during Covid-19 runs instant and fast-paced. The development of science and technology, especially the Internet and social media has a very strong influence. Not only does it affect the daily activities of people's lives, but also the activities of the professional world, especially in crisis communication that is considered more complex Salma, (2021).

Indonesia has been undergoing global crisis due to COVID-19 pandemic. The weakening of economic sector is caused by the restriction of activity and many companies of various fields are unable to survive because of undergoing economic contraction Pratiwi, (2021).

In turn, the government continues to encourage task force volunteers to assist in the distribution of now-available vaccines around the country, and is still currently accepting new volunteers. In these difficult times, many people needed the help from volunteering organizations in order to relieve their distress caused by COVID-19. Sudden depression, financial crisis, lack of supplies and awareness are all becoming the problems that volunteers would face while volunteering during the pandemic. This intergroup viewpoint is yet to be related to volunteering, which is a 
fundamentally different type of helping in that it requires the constant contribution of time, effort, and expertise to others, mostly on a regular basis and often for several years Gray and Stevenson, 2019) During pandemic situation and conditions, it is really important that message we show reflects empathy for what has happened. The media that attracts a lot to the transfer of marketing content to this media is online media Pinariya, et., al (2020). In this case, the issue on how community engagement includes Indonesia's COVID-19 task force volunteers as humanitarian aids during this ongoing disaster remains unclear.

\section{Theoretical Framework}

There are numerous descriptions of volunteering in the academic literature. According to Butcher and Einolf (2017), Volunteering is one of the ways of social and community engagement. People participate in social movements through volunteering, which fosters interpersonal engagement, accountability, and decision-making for a shared purpose. Safrit \& Schmiesing (2012) defines volunteers as human resources that are recognized and praised for their individual and mutual commitments to the mission and objective of the organization. They are identified as someone who goes beyond and outside the confines of their paid jobs and usual duties to devote time and service to a non-profit cause in the hope that their action benefits others while also rewarding themselves.

Volunteering activities involve relationship management and non-profit organizations. Nowadays, the maintenance of relationships also requires modernization such as the usage of social media. Kinsky, et., al. (2014) stated that volunteers could play important roles as social media strategists and become an aid to strategic communication. While informal volunteerism thrives at the individual and community organizational levels, a steady number of people continue to volunteer within formal organizations.

\section{Community Engagement}

According to Johnston and Taylor (2018), community engagement is defined as a relational process that facilitates understanding and evaluation, involvement, exchange of information and opinions, about a concept, issue or project, with the aim to build social capital and enhance social outcomes through decision making. In recent years, corporate organizations have started to understand the importance of taking responsibility that can appear to be more acceptable and consistent with community standards since they were created by CE. Whereas Charmorro-Koc and Caldwell (2018) define community engagement as a bottom-up participatory mechanism that is distinguished by information exchange as an essential component for community participation in social innovation initiatives.

According to Charmorro-Koc and Caldwell (2018), community engagement can be distinguished by these 4 characteristics. The first one is the bottom-up approach, as the acquisition of new ventures that are feasible within the framework and within the expertise of local citizens. It is a collective and participatory mechanism in which ideas emerge from the community itself. Followed by shared and assembled knowledge. Engagement by information sharing through different communities is regarded as a type of collective and public engagement strategy. whereas assembled knowledge is a method of group interaction in which people shared a mutual purpose and collaborated to develop ideas and put them together as a solution that resulted from the joint effort.

The third aspect is described as focus on community in-place, by integrating various collaborative mechanisms and media by which participants could react to the information exchange, a wider spectrum of engagement was possible. The final aspect is participation and co-production, where technology is used, and has recently been expanded and enhanced as a result of the public's increased access and affordability of innovations such as mobile devices, Websites, and digital production. The four community engagement elements have confirmed the claim that the community engagement model is dynamic.

As a concept, Johnston and Taylor (2018) stated that community engagement features the act of connection, as a form of energy exchange between individuals, coming second in importance only to the fulfilment of most of one's basic needs. Interaction aims to communicate the perceptions of a given society to those who are unfamiliar to it, since these form the foundation for social structure and hence are a key component of engagement. Participation, as a mechanism for further development; promotes a sense of responsibility and therefore ensures a felt need is involved and that the tasks are done appropriately which then employs useful cultural knowledge. Lastly, involvement by socially mediated forces to 
affect meaning through bonding and association, being communicatively and culturally linked within communities, situations and contexts, is intended to achieve or evoke a result on a personal, organizational, or social level.

In the role of public relations, community engagement is often described as an essential concept that is used to develop and maintain a mutually beneficial relationship between one society and another. The two authors have developed structural information of elements for community engagement. Charmorro-Koc and Caldwell (2018), have identified the bottom-up approach that has a similar definition of connection element discussed by Johnston and Taylor (2018), in a way that both authors have a similar approach of elemental values. Therefore, in order to continue this research, this paper will be written based on Johnston and Taylor (2018), exploration of community engagement.

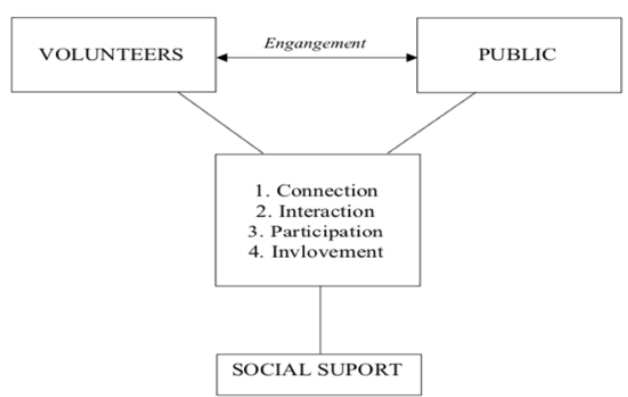

Figure 1. Dimension of Elements of Community Engagement

Source: Chamorro-Koc and Caldwell, 2018

In the research community, assumptions and perceptions are always shared and discussed, breaking down different ways of seeking knowledge in reality as well as reviewing several approaches in order to make meaningful research. According to Tracy (2020) Paradigms are preferred ways of understanding reality, building knowledge, and gathering information about the world. It is a widely recognized research accomplishment that offers conceptual challenges and solutions to a group of professionals for a period.

Different disciplines use different terminology and paradigm categorization schemes. There are a number of frequently applied and differentiated paradigms - positivist or post-positivist, interpretive, critical, and postmodern / post-structural. Hence, the interpretive paradigm is going to be applied for this research in particular. Interpretivism is sometimes pitted against positivist approaches in terms such as hard sciences versus social sciences, numbers against discourse, generalisability versus situatedness, and so on Denzin \& Lincoln, (2018) From an interpretive's perspective, reality is seldom something "out there," which a researcher can clearly explain, describe, or translate into a research report. Rather, conversation, interaction, and experience create and recreate both reality and information. As a result, the researcher often filters information about reality (Tracy, 2020).

This research design is specifically using the methods of qualitative study. In general, qualitative research is distinguished by inductive approaches to information generation aimed at generating significance (Leavy, 2014). This methodology is used by researchers to explore; to rigorously study and learn about social phenomena; to unpack the meanings people ascribe to actions, circumstances, incidents, or artifacts; or to gain a comprehensive understanding of some aspect of social life.

\section{Result and Discussion}

Overcoming the obscurity in travel industries for unpredicted time, several researcher found the new normal behaviours. According data from Mc \& Kinsey (2020) about market insights during pandemic COVID-19, this disruptive reliance on remote technologies would bring a changes in people's perspective about travelling. The rising.

In terms of following up with the public and identifying internal connections, there might be a slight problem in the task force volunteer's data coordination and management.

"For me, because I feel myself in tracing, I say back and forth in tracing. Because my little one is positive, positive is January, the tracing period is July? That's my son recovered. If my child dies, am I not angry with the person who traced it? He said the reason was that the data just came in. That's really random data in us. Overlapping, awesome. Volunteer acceptance is actually overlapping." (M. Maria, Personal Communication, 1 August 2021).

"Yes, so when someone gets hit, the data will be sent to us. We will trace his family, using our own tools. I went down, to swab his family. Suppose there are 5 people, 1 is affected, the rest we separate 
first so that it doesn't get more contagious. The rest we trace. We provide the boarding house, we allow it first with the RT and then separate it. After that, we will send her help and needs for 14 days." (W. Indrawan, personal communication, 1 August 2021).

"Volunteers are part of the community itself. By always improving their knowledge and skills through training organized by BKR, volunteers will continue to move together to embrace the community in their area to carry out health care programs, invite vaccinations, distribute aid, do tracing and so on.." (P. Suryotomo, Personal communication, 1 August 2021).

Community tracing and monitoring are both considered as very necessary in order to keep track with the virus dispersion amongst the public. However, it is still lacking based on Maria's experience and she stated that this has delayed information exchange and needed to be handled accordingly in the future, whereas Indrawan explained that tracing is to be done right after a person was infected with the virus. Both task force and volunteers remain connected even after the person has fully recovered.

"I think there are still many in the field today, many volunteers who when their family is sick, they are also confused about where to go. They are also confused, how is the flow, what is the puskesmas (public health service post) like. That's what we can also convey to the public. One of the hardest things in a disaster, be it in a pandemic, is actual communication. How to communicate a disaster is not the same as communicating other things because if we are too scary, it has an impact on the community but if we cover it up it will also have an impact.." (M. Hidayat, Millennials for a better humanity webinar, 10 August 2021).

Hidayat stated that even as volunteers, the responses and information exchange are still not optimal, and as a result, they sometimes do not know the workflow for dealing with COVID-19 when their family is infected with the virus. He then further explained that communication is one of the most difficult aspects of a disaster, whether it is a natural disaster or a pandemic. How to communicate a disaster is not the same as communicating other things because being too intimidating will have an impact on the community, but covering it up will have an impact as well.

\section{Interaction, Participation and Involvement}

The third point in the interview guideline questions about the task force volunteers' engagement in the community in order to assist and empower the public during COVID-19 as well as their recommendation in developing a better volunteering approach for the public. This part also examines their most challenging question about COVID-19 when responding to media or public inquiries. This could also depict the task force volunteer's willingness and responsibility while participating in this operation.

"Initially, one of the biggest challenges faced was how to fight the stigma that exposure to COVID-19 was a taboo subject. At the beginning of the pandemic, if someone was exposed to COVID-19 they tended to hide for fear of being ostracized. Even now, in certain areas, they still expel or ostracize their exposed citizens. Likewise with COVID19 volunteers, if someone openly becomes a COVID-19 volunteer, not necessarily the community can accept it well. This is because it is considered that the volunteer also brought the virus." (T. Pantouw, personal communication, 1 August 2021).

"And indeed the conditions at that time were still taboo, lest those who were affected in our place be ostracized. Because honestly, here in Pondok Betung, there are about eighteen thousand residents, so I'm a bit concerned." (W. Indrawan, personal communication, 1 August 2021).

As stated above and according to the researcher's findings, during the early days of the coronavirus pandemic, Indonesian citizens indeed regard this coronavirus disease as a taboo subject, and there may still be a percentage of people who believe so in some locations. As time goes by, with the preparation from the national task force, awareness and safety protocols are being reinforced by 
ensuring the public that these volunteers are available and offer long-time support.

"I can say that one of our shortcomings was facing this pandemic in the first place. Because disaster communication to the community is still lacking, so it is felt until now. So communication if we relate to disasters is very important before, during, after, and after disasters. So that is our problem, one of our tasks during this pandemic is to be able to fight hoaxes too. So, giving information, fighting hoaxes, don't spread it again. It's from me." (M. Hidayat, Millennials for a better humanity webinar, 10 August 2021).

Furthermore, the lack of preparation for dealing with COVID-19 from the start has a long-term impact. As a result, hoaxes are all over the community. According to Hidayat, communication is critical during a pandemic and must be maintained including before, during, and after the pandemic ends as Ersing (202) has stated that the concept of community development encompasses both pre-disaster planning and post-disaster recovery.

"We know that not everyone will accept or even listen to what we have to say, however, it would be worse if we remained silent. The easiest example is when you are in a public place/public transportation. We can remind if someone doesn't follow the health protocol properly, if in doubt, report it to the authorities." (T. Pantouw, personal communication, 1 August 2021).

With the willingness to participate and provid endless support to the public, Pantouw believes that this can create an understanding for the task force volunteers to interact with the public even though it seemed like a repetitive appeal.

"From the center, it only provides face shields, masks, thermo guns, and hand sanitizers, and in my opinion, they are given to people, not to us. And we thought, well, let's carry the symbol on the chest, use our own money. Because it's my own responsibility, not the center. We give medicine, we take care of the hospital until BPJS for Covid health. People and their surroundings are taboo, which I said earlier. Well, that's our job.
As soon as we hit it, we'll go down. We will say, "Covid is like this, you know, this is that" we will tell the RT, don't ignore it and they will understand. That way they are in control and they are calm. Families who are affected are also calm, because when they are sick with COVID, if they are happy, they will recover quickly. But if they get mentally first, well, it's dangerous for their mentality." (W. Indrawan, personal communication, 1 August 2021).

Indrawan has taken initiative to use his own expenses because of the responsibility that he naturally experienced in order to assist the public. In addition, to connect with the taboo perception towards COVID-19, he also further explained that it is the task force volunteer's job to take this matter and explain it to the community. Everything will be under control, and the impacted families, as well as the surrounding neighborhood, will be at ease. They will recuperate faster if they remain content. Therefore, Pantouw (personal communication, 1 August 2021) stated that the Public Communications team, especially those in the community, must always carry out continuous engagement and education to all levels of society. This was difficult earlier because many people were opposed to hoaxes and even certain beliefs. Although citizens continue to complain, Pantouw believes that if the government remains steadfast, the public will continue to accept and follow the government's suggestions.

Nowadays the task force volunteers are currently focusing on encouraging people to get vaccinated as it is now widely available for free. By the task force's interaction with the public, some groups of people are still hesitant to get vaccinated due to several reasons.

"Yes, because they are afraid, and the education is difficult. That's why I was. So while waiting for the vaccine, I said, it's like the Sinovac vaccine is because, in the past, I've heard that a senior lab officer said, "Sir, my son is hot" "Yes, it's good, ma'am, if it's hot, it means that the army in its body is fighting back." So, until now, I remember I thought that too. As for Astrazeneca, it's because the virus is artificial, so it's not a 1-tok corona virus, right, so our soldiers are "what is it, what's wrong" in a confused body. So all the soldiers in our body, attack them so 
that's why the body has a fever, a headache, and I said so. They just said "oh, I see" finally, yes, there are those who want to be vaccinated. But only $21 . "$ (M. Maria Personal Communication, 1 August 2021).

As one of the task force volunteers who also oversees community vaccinations, Maria remarked that some people still have reservations about particular vaccine brands, such as astrazeneca. As a result, she must explain with a new perspective and alter her personal communication so that it is properly received and understood by the public.

"... there are some who are sad, 2 or 3 weeks ago, at 1 am someone called, the phone didn't pick up, suddenly in the morning I saw someone asking for help. "Sir, please help I need a car and oxygen, even though it's not in this area. In Pesanggrahan. I said "I'm sorry ma'am, how is your father's condition?" then he replied "Pak Indra sorry, thank you, but his father is not there". Even though I don't know it, so I feel sad there. But now it's familiar, WhatsApp asks about family. Until the sub-district head if there is anything until the discussion. Yes, they feel calm, finally their position is carried out and safe. And it just so happens that this area has the most population, and with virtual forms here and there, thank God, everything is stable, everything can be stabilized." (W. Indrawan, personal communication, 1 August 2021).

Assisting the community, explaining and openly demonstrating the proper protocols, according to Indrawan, may surely enhance the bond with the public since task force volunteers become capable of delivering a message that is easily understood, which can then be further developed into trust. It is also necessary for Indrawan to acquire the public's trust in order to completely understand what the public needs and how the task force volunteers should aid them.

Pantouw (personal communication, 1 August 2021) also added that the task force has also held Key Opinion Leaders from the national level to the neighbourhood community unit (RT/RW) in terms of communication and involvement. Volunteer capacity building has been gradually improving for the previous two years, initially with online training and progressing to holding teaching practices.

In order to anticipate the upcoming situation that cannot be predicted, the figure above shows Indrawan's proposed plan to prevent the spread of COVID-19 virus that constantly develops new variants. To be highlighted in this research, he suggested providing self-isolation rooms in each neighborhood or district so that those who are not exposed to the virus can be separated from those who are already infected. In addition, Indrawan also advised to engage and constantly approach families by educating them to do mandatory self-isolation for those who are exposed to the virus.

"So I think it would be very helpful if there were volunteers to provide information, even those that match their field of making applications through technology, it is one of the fields that is really needed at this time. So, that's what can be done during a pandemic." (M. Hidayat, Millennials for a better humanity webinar, 10 August 2021).

Furthermore, Hidayat added that with the advancement of technology and newer ideas in this era, volunteers can use this advantage to contribute and maintain participation as well as involvement in handling COVID-19 in Indonesia.

"If it's a patient, maybe we can work with a psychologist, so we have several volunteer coordinators in the SATGAS, where we gather psychologists, communication experts, or volunteers to support. Mas Hari has even mentioned that there are many things that we must support for an isoman society. There are even movements that collect, help isoman friends in terms of food, motivation, we can do that. Now, if we want to go to the field, for example, we just have to look for the analogy, look for the organization and institution, so that we can be educated more. So that what we do is conceptualized, so the basis is there. Plus there will be networking." (M. Hidayat, Millennials for a better humanity webinar, 10 August 2021). 


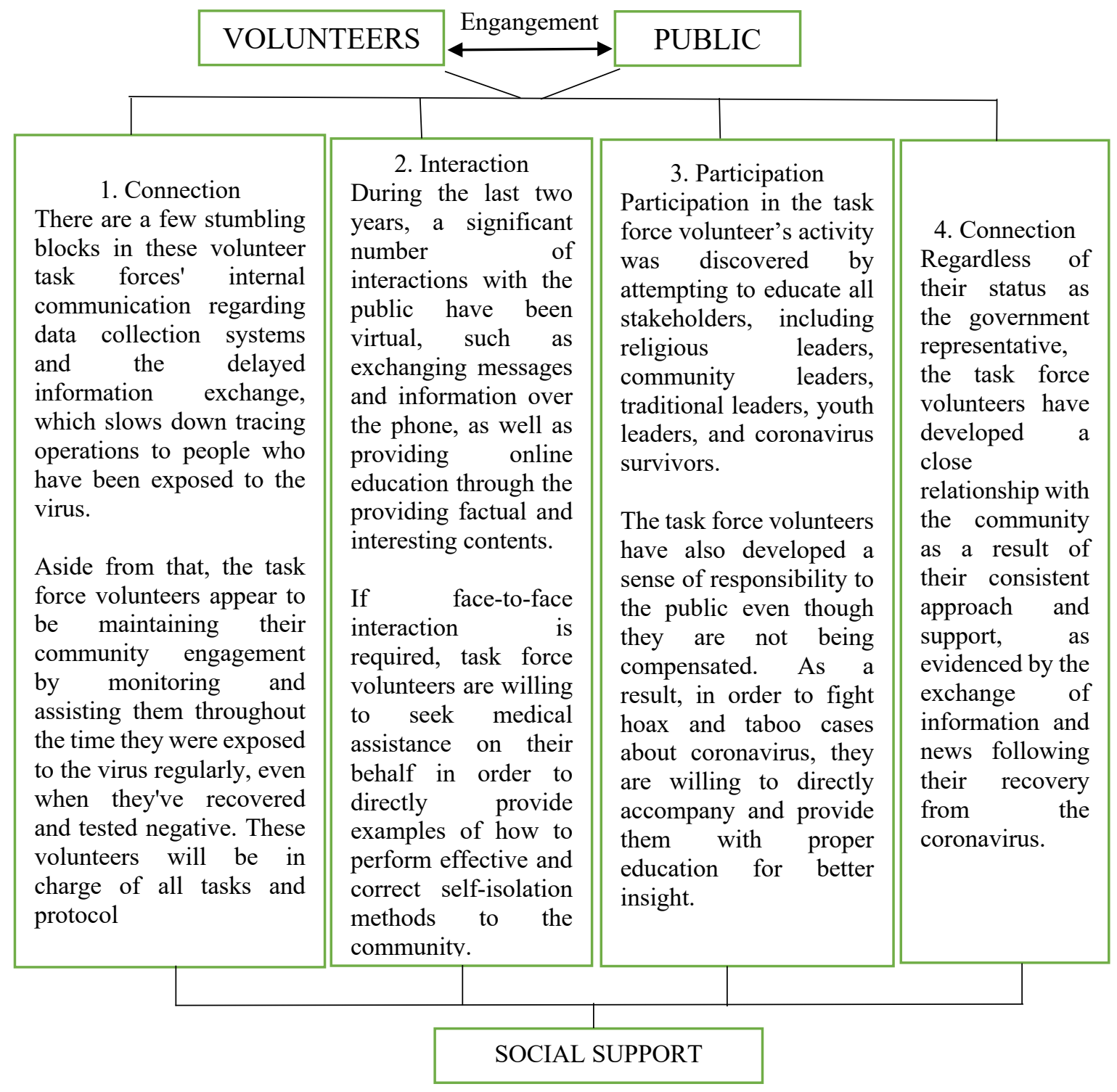

Figure 2. Implications of Dimension of Elements of Community Engagement (Source: Chamorro-Koc and Caldwell, 2018 \& Author processed data, 2021).

\section{Conclusion}

The researcher discovered several novel approaches that represent the role of volunteers that can act as social supporters after conducting an in-depth investigation into volunteerism during this pandemic, specifically the national task force volunteers. Thus, the researcher concluded that during this COVID-19 pandemic, the role of these task force volunteers can be described as a link between the public and the government.

Not everyone can fully process or understand the government's announcement. However, with the existence of the task force volunteers being close to reach, and being united to the public, they have conveyed this message to a better understanding for the community. The task force volunteers have also provided support and empowerment to the public by constantly encouraging them to follow the protocols and instructed guidelines that needed to be conducted during the coronavirus exposure. Alston (2020) stated that this prioritization of environmental health arises not only as a result of environmental disasters highlighting the importance of these challenges to practice, but also as social workers, or, in this case, volunteers increasingly recognize the need to advocate for environmental health.

There are still a lot of families who don't know how to respond to the impact of the virus, which is common as families must decide how to respond quickly, especially when disasters strike unexpectedly and cause widespread devastation (Alston, 2020). Thus, the researcher found that with the help of the task force volunteers, families are being guided and given directions on how to properly handle the 
situation as it is fundamental to respond to the disaster as carefully and as soon as possible.

Many volunteer activities have changed as a result of the advancement of digital technology; in order to adapt to the current situation, both task force volunteers and the public are trying to make use of what can still be accessed as long as social distancing is maintain. Therefore, interaction through online platforms has been very beneficial and will continue to be improved in order to maintain community engagement. Despite being involved based on their free will, several initiatives have been done by the task force volunteers outside of the central directives in order to further improve the engagement in the community. As this is an ongoing situation, they are still willing to be involved in planning new efforts and contents to make sure that the public are properly informed and prepared for the next response.

\section{References}

Butcher, J., \& Einolf, C. J. (2017). Perspectives on Volunteering voices from the south. Switzerland: Springer International Publishing

Chamorro-Koc, M., \& Caldwell, G. (2018). Viable futures through design: Community engagement experiences in the creative industries. Creativity Studies, 11(1), 213-229. https://doi.org/10.3846/cs.2018.85

Denzin, N. K., \& Lincoln, Y. S. (2018). The sage handbook of qualitative research. California: SAGE

Gorbiano, M. I. (2020, March 2). BREAKING: Jokowi announces Indonesia's first two confirmed COVID-19 cases. The Jakarta Post. Retrieved 6 April 2021 from https://www.thejakartapost.com/news/20 20/03/02/breaking-jokowi-announcesindonesias-first-two-confirmed-covid19-cases.html.

Fachriansyah, R. (2020, May 28). 'Corona is like your wife': Minister Mahfud slammed for 'sexist' comment. The Jakarta Post. Retrieved 17 August 2021 from

https://www.thejakartapost.com/news/20

20/05/28/corona-is-like-your-wifeminister-mahfud-slammed-for-sexistcomment.html.

FT Visual \& Data Journalism team. (2020, October 18). Covid-19: The global crisis
- in data. Financial Times. Retrieved 1 August 2021 from https://ig.ft.com/coronavirus-globaldata/.

Gray, D., \& Stevenson, C. (2019). How can 'we' help? Exploring the role of shared social identity in the experiences and benefits of volunteering. Journal of Community \& Applied Social Psychology, 30(4), 341-353. https://doi.org/10.1002/casp.2448

Johnston, K. A., \& Taylor, M. (2018). The handbook of communication engagement. Hoboken: John Wiley \& Sons, Inc.

Kinsky, E. S., Gerlich, N., \& Drumheller, K. (2014). Race for Crisis Control: Attitudes and Giving Responses after Susan G. Komen for the Cure Pulled Planned Parenthood Funding. In R. N. Gerlich (Ed.), Public Relations in the Nonprofit Sector: Theory and Practice (pp. 84102). NY: Routledge.

Leavy, P. (2018). Research design: Quantitative, qualitative, mixed Methods, Arts-Based, and community-based participatory research approaches. NY: The Guilford Press.

Mendy, A., Stewart, M. L., \& VanAkin, K. (2020, December 14). A leader's guide: Communicating with teams, stakeholders, and communities during COVID-19. McKinsey \& Company. Retrieved 6 April 2021 from https://www.mckinsey.com/businessfunctions/organization/our-insights/aleaders-guide-communicating-withteams-stakeholders-and-communitiesduring-covid-19\#.

Pinariya, J., M., Yulianti, W., Mitha, J., \& Larasaty, P., N. Create Successful Content Media as Crisis Mitigation in Tourism Industry During Covid-19 Pandemic. Komunikasi Ikatan Sarjana Komunikasi Indonesia, Vol. 5 (2), 2020, 254-261.

Pratiwi, M. (2021). Business Survivability: Social Media as a Channel. Jurnal Komunikasi Ikatan Sarjana Komunikasi Indonesia, Vol. 6 (1), 2021, 121-128

World Health Organization. (n.d.). Coronavirus disease (COVID-19). World Health Organization. Retrieved from the WHO 
Website:

https://covid19.who.int/region/searo/cou ntry/id

Worldometers. (2021). COVID-19 Data in Indonesia. Worldometers. https://www.worldometers.info/coronavi rus/country/indonesia/.

Safrit, R. D., \& Schmiesing, R. (2011). Volunteer Models and Management. In T. D. Connors (Ed.), The Volunteer Management Handbook: Leadership Strategies for Success, Second Edition (Second, pp. 1-30). New Jersey: John Wiley \& Sons.

Salma, A. N., (2021). Preparing for the Worst Crisis Scenario on the Flag Carrier Garuda Indonesia in Digital Era. Jurnal Komunikasi Ikatan Sarjana Komunikasi Indonesia, Vol. 6 (1), 2021, 53-61

Setiawati, S., \& Azwar, M. K. (2020, April). COVID-19 and Indonesia. ResearchGate. Retrieved 16 April 2021 from

https://www.researchgate.net/publication 1340645813 COVID-19 and Indonesia

Singarimbun, K. (2021). E-Church as a Virtual Service Communities During COVID-19 Pandemics. Jurnal Komunikasi Ikatan Sarjana Komunikasi Indonesia, Vol. 6 (1), 2021, 96-106

Tracy, S. J. (2020). Qualitative research methods: Collecting evidence, crafting analysis, communicating impact. Wiley Blackwell. 